\title{
Impact of hydrolyzed lactose by $\beta$-galactosidase enzyme on the physicochemical and organoleptic properties of fermented camel milk
}

\author{
Alaa H. Ibrahim* \\ Department of Animal and Poultry Breeding, Desert Research Center, Cairo, Egypt
}

\section{A B S T R A C T}

\begin{abstract}
The present study was conducted to evaluate the influence of lactose hydrolysis by using two different strategies (by addition of $\beta$-galactosidase (HA-LACTASE") before fermentation of camel milk to get hydrolyzed camel milk as substrate that included three levels of lactose-hydrolyzed milk (LHM) 25, 50 and $90 \%$ or together with the starter cultures during fermentation (co-hydrolysis)) on the microbiological, physicochemical and sensory properties of fermented camel during manufacturing and the storage period of 21 days at $5^{\circ} \mathrm{C}$. In general, the results showed a significant $(P<0.05)$ reduction in fermentation time with an increase in the level of lactose hydrolysis. The co-hydrolysis fermented milk exhibited a significant $(P<0.05)$ decrease in the fermentation time $(279$ min) in comparison to control treatment $(452.5 \mathrm{~min})$. After $6 \mathrm{~h}$ of the incubation period, the viable cell counts were more outstanding in the co-hydrolysis and LHM $90 \%$ fermented milk, about 1 log cycle higher than other treatments. The mean values of pH were a highly significant $(P<0.05)$ dropped in co-hydrolysis and LHM 90\% samples and reached to pH 4.6 in 6 hours, whereas the control, LHM 25 and $50 \%$ samples reached to the near of the same degree of $\mathrm{pH}$ in 8 hours of the fermentation process. Furthermore, the higher amount of exopolysaccharide (EPS) was found in co-hydrolysis fermented milk $262.3 \mathrm{mg} / \mathrm{kg}$ followed by LHM $90 \% 250.3 \mathrm{mg} / \mathrm{kg}$, while control, LHM 25 and $50 \%$ treatments had the lowest amount of $178.3,185.3$ and $197.7 \mathrm{mg} / \mathrm{kg}$, respectively. The higher amount of EPS in co-hydrolysis and LHM $90 \%$ treatments caused a concomitant increase of the apparent viscosity and a significant $(P<0.05)$ decreased in susceptibility to syneresis in comparison to other treatments. Moreover, the co-hydrolysis fermented camel milk had significantly $(P<0.05)$ higher ratings for all sensory characteristics and more liked than other treatments. Although the LHM $90 \%$ samples had a better rheological characteristic, the panelists rated as unacceptable because of the strong sweet taste. Results showed that the simultaneous addition of enzyme and starter together demonstrated to be a satisfactory strategy in making fermented camel milk with high quality in the texture and overall acceptability beside its beneficial properties as a functional dairy product.
\end{abstract}

Keywords: Lactose hydrolysis; $\beta$-Galactosidase enzyme; Fermented camel milk

\section{INTRODUCTION}

Among the domesticated mammals, camels (Camelus dromedarius) play a significantly important role in the food security of the Bedouins (Arabic pastoral community's), especially in the hot and arid environments of Africa and Asia where poor nutrition is the major shortcoming. Nowadays, there is a fast-growing demand for camel milk and its products not only in the Gulf area and North Africa but also in the European markets due to valuable nutritional value and therapeutic properties (Al-Juboori et al., 2013; Faye, 2015; Khalesi et al., 2017). In Dubai, Saudi Arabia and some areas of North Africa some camel milk products, such as fresh or pasteurized camel milk flavored, ice cream and cheese, have become available in supermarkets, but the fermented camel milk is not appearing in markets, where the fermented camel milk is still not developed enough for commercial application (Faye and Bonnet, 2012) except in Central Asia (Akhmetsadykova et al., 2015).

Some reports that traditional processing camel milk into fermented products is described to be difficult, largely due to the presence of a greater content of antimicrobial growth-inhibitor compounds in camel milk, which caused a lower growth rate of starter cultures and longer fermentation time, which caused many quality problems in the final product (Hashim et al., 2009, Al-Zoreky and Al-Otaibi, 2015; Ibrahim, 2015a). Moreover, the lactic

\footnotetext{
${ }^{*}$ Corresponding author:

Alaa H. Ibrahim, Department of Animal and Poultry Breeding, Desert Research Center, Cairo, Egypt. Tel.: +201226916217.

E-mail: alaa.drc@gmail.com
}

Received: 29 January 2018;

Accepted: 24 August 2018 
fermentation did not produce a reality curd, but the curd formed was very weak consistency and it's flow-able. This is mainly due to its unique composition because of low total solids content, a very low concentration of $x-\mathrm{CN}$ and $\alpha-\mathrm{CN}$ in camel milk than in cow milk that directly influences the clotting ability of milk (Attia et al., 2001; Sagar et al., 2016).

Recently, few scientific studies have been mentioned to improve the fermentation process of fermented camel milk. These attempts have focused on producing fermented camel milk products with high consistency by adding some ingredients to improve fermented camel milk texture, including; the addition of hydrocolloids (Hashim et al., 2009; Ibrahim and Khalifa, 2015a), skim milk and whey protein powder (Mortada and Omer, 2013, Sakandar et al., 2014; Ibrahim, 2015a).

However, development in camel dairy microbiology starter cultures was largely limited and based on commercial starter cultures (Akhmetsadykova et al., 2014). These commercial mesophilic starter cultures are not adapted to the growth conditions in camel milk because of the presence of inhibitory agents (Holzapfel, 2002). To improve the traditional fermentation of camel milk products, the optimization and controlled fermentation growth conditions of commercial starter cultures is a very important strategy for producing fermented camel milk products with the high quality of the texture and consumer acceptability (Hassaïne et al., 2007).

Furthermore, it is known that development of acidity in any types of fermented milk mainly depends on the type and quantity of available carbohydrates in growth medium and relies entirely on the activity of the starter cultures. Thomas and Crow, (1983), Vénica et al., (2013 and 2014) and Schmidt et al., (2016) clearly observed that the metabolic activities of the starter during fermentation depends on the strains and their association's factors such as (nitrogen and carbon $\mathrm{C} / \mathrm{N}$ ratio and fermentation conditions, e.g. temperature, $\mathrm{pH}$...). Furthermore, the presence of high level of easily fermentable sugar (glucose) gives remarkable microbe growing and reducing in processing time.

Lactose is the main carbohydrate source in milk and can be hydrolyzed by the $\beta$-galactosidase enzyme into monosaccharides (glucose and galactose). The $\beta$-galactosidase (EC 3.2.1.23) enzyme can be isolated from e.g. microbial (bacteria, fungus, and yeast) or animals, plants (Husain, 2010 and Harju et al., 2012). Amongst all the available sources $\beta$-galactosidase obtained from Kluyveromyces yeasts are most commonly applied for the purpose of developing reduced-lactose or lactose-free dairy products to avoid milk lactose consumption by lactose-intolerant individuals as functional foods or to avoid unwanted technological characteristics, such as the crystallization of this carbohydrate in some dairy products or improving the sweetness, flavour and texture of the dairy products (Martins et al., 2014, Vénica et al., 2014).

More recently, there are few publications about the influence of lactose hydrolysis by exogenous $\beta$-galactosidase on the rate of sugar consumption by starter cultures and the production of derived compounds as well as the physicochemical, rheology and sensory characteristics of the final fermented milk product. Ismail et al., (1983), Toba et al., (1986), Vénica et al., (2013 and 2014) and Wolf et al., (2015) found that the reduced-lactose yogurts made with added $\beta$-galactosidase improved the growth rate of the starter cultures by providing the optimal conditions for rapid growth immediately during the first hours of incubation and, also reduce the fermentation time. In addition, Nagaraj et al., (2009) and Schmidt et al., (2016) observed that yogurts made with the addition of $\beta$-galactosidase caused a significant increase in the amount of exopolysaccharide (EPS) producing results in improving the texture properties of yogurts.

However, there are no data published was undertaken to investigate the possible advantages of using lactosehydrolyzed camel milk in the manufacture of fermented camel milk and there is no information concerning the types of changes which might occur in physiochemical, microbiological and sensory properties during the manufacture and storage. Therefore, the aim of our study was to evaluate the influence lactose-hydrolysis by addition $\beta$-galactosidase (HA-LACTASE ${ }^{\mathrm{TM}}$ ) before fermentation or together with the EPS-producing starter cultures on the changes of the microbiological, physicochemical and sensory properties of lactose-hydrolyzed fermented camel milk during the manufacture and its quality during storage period of 21 days at $5^{\circ} \mathrm{C}$ compared to the traditional one.

\section{MATERIALS AND METHODS}

\section{Camel's milk source}

Fresh raw camel milk (40 L), from healthy Magrabi camel, was obtained from camel farms in Sidi-Barani areas, Matrouh Governorate, North West Coast, Egypt. The milk was transported to the laboratory in the icebox and stored at $5^{\circ} \mathrm{C}$ before analysis. The gross composition of raw milk was: Total solids $12.73 \%$; fat $3.55 \%$; total protein $3.59 \%$; lactose concentration $4.47 \%$; titratable acidity $0.18 \%$ and pH 6.71. The gross composition was determined by using a Lactoscan milk analyzer (Model Lactoscan SL, Milkotronic Ltd, Bulgaria) calibrated for camel milk.

\section{Starter culture}

A commercial lyophillized direct vat set (DVS®) YoFlex ${ }^{\circledR}-$ L901 starter culture, a blend of Streptococcus 
thermophilus and Lactobacillus delbrueckii subsp. bulgaricus (1:1) obtained from (Chr. Hansen, Hørsholm, Denmark) was used in this study. According to starters' manufacturer specifications, this strain characterized by high viscosity, high gel firmness, mouthfeel, and smoothness development during fermentation.

\section{Preliminary experiments}

\section{Preparation of camel milk base}

Preliminary experiments were made to study the process of camel milk lactose enzymatic hydrolysis. The most favorable lactose enzymatic hydrolysis degree was applied for the preparation of fermented camel milk. For prepared lactose hydrolysis of camel milk before fermentation, five equal parts of camel milk was pasteurization at 72 for $15 \mathrm{~s}$ and equilibrated to $40^{\circ} \mathrm{C}$ in a water bath, $0.5 \mathrm{ml} / \mathrm{L}$ of a soluble commercial $\beta$-galactosidase (HA-LACTASE ${ }^{\mathrm{TM}}$-Chr. Hansen, Hørsholm, Denmark) enzyme from Kluyveromyces lactis with a declared activity of $5200 \mathrm{NLU} / \mathrm{ml}$ was added (as per supplier's product sheet). Hydrolysis were carried out under continuous stirring with a mixer at $150 \mathrm{rpm}$ at $40 \pm 1^{\circ} \mathrm{C}$ for $1,2,3,4$ and $5 \mathrm{~h}$. After each time of hydrolysis reaction, the camel milk samples were heated to a $90^{\circ} \mathrm{C}$ for $15 \mathrm{~min}$, this heat treatment caused inactivated the $\beta$-galactosidase enzyme. Lactose hydrolysis degree was determined during these periods and achieved the final lactose concentrations approximately 18, 25, 50, 78 and $90 \%$, respectively. All the camel milk enzymatic hydrolysis experiments were repeated in duplicate.

\section{Experimental design}

To evaluate the effects of the degree of lactose-hydrolyzed (LH) on camel milk fermentation properties, in total, fermentation was carried out simultaneously for five basic trials divided into the following three categories: The first, one treatment was prepared without enzyme addition (control), the second, four vats (4 L capacity) were operated simultaneously in two methods as follows:

Method I: Fermented camel milk was prepared by added $0.5 \mathrm{ml} / \mathrm{L}$ of $\beta$-galactosidase to the camel milk at the same time with the yogurt starter culture (co-hydrolyzed).

Method II: Fermented camel milk was prepared with lactose-hydrolyzed (LHM) milks at the three percentages of 25,50 and $90 \%$ of lactose-hydrolyzed camel milk.

\section{Fermented camel milk manufacture}

Fermented camel milk was made by using the traditional method (Schmidt et al., 2016) adapted to laboratory scale and repeated in duplicate. The control, co-hydrolyzed and lactose-hydrolyzed milk (LHM 25, 50 and 90\%) were heat treated at $90^{\circ} \mathrm{C}$ for $15 \mathrm{~min}$ and then cooled to $42^{\circ} \mathrm{C}$ prior to inoculation with $0.02 \%(\mathrm{v} / \mathrm{v})$ frozen starter cultures and stirred for 10 min according to the starter producer's recommendations. At this moment, the $\beta$-galactosidase enzyme was added to the experimental (co-hydrolyzed) camel milk at the same time with the yogurt starter cultures. Inoculated milk was filled in $150 \mathrm{ml}$ plastic jars and incubated at $42^{\circ} \mathrm{C}$ for $8 \mathrm{~h}$. Fermented camel milk products were immediately cooled and stored at $4 \pm 1^{\circ} \mathrm{C}$. Fermented camel milk samples were analyzed during the fermentation period of $(0,2,4,6$, and $8 \mathrm{~h})$ and after refrigerated storage at $1,7,14$ and 21 days intervals for microbiological, physiochemical and sensory evaluation. Fermentation times were defined as the time required for decreasing the $\mathrm{pH}$ value to a final $\mathrm{pH}$ of 4.6.

\section{Chemical analysis}

The $\mathrm{pH}$ values of fermented camel milk samples were measured in duplicate directly after homogenized samples by using a digital pH meter HI 8521 pH-Meter (model pH 211 microprocesor; Hanna Instruments- Germany). Titratable acidity was measured by titration with $0.1 \mathrm{~N} \mathrm{NaOH}$ and expressed as a percentage of lactic acid according to the methods of AOAC (2005).

\section{Determination of lactose concentration}

The lactose concentration in milk and its fermented camel milk hydrolyzed products were determined spectrophotometrically by using the Lactose and D-Galactose rapid assay kit method (Megazyme ${ }^{\circledR}$ International Ireland Ltd., Bray, Wicklow, Ireland), according to the manufacturer protocol. Lactose concentration was measured at the absorbance reading $\mathrm{A}_{340} \mathrm{~nm}$ by using a scanning UV-visible double-beam spectrophotometer (Jenway 6850-UK) for each replication.

\section{Exopolysaccharide isolation and quantification}

The EPS separation in fermented camel milk according to the method of Zisu and Shah (2003) and quantified in duplicate at $\mathrm{A}_{490} \mathrm{~nm}$ by using the phenol-sulphuric method of Dubois et al., (1956) using the glucose as a calibration line.

\section{Enumeration of starter culture}

Enumeration of yogurt bacteria was determined by using the pour plate technique with serial dilutions of fermented camel milk sample solution $(1 \mathrm{ml})$ were homogenized for one minute in $9 \mathrm{ml}$ of $0.1 \%(\mathrm{w} / \mathrm{v})$ peptone water (Difco, Detroit, MI, USA). S. thermophilus was counted in M17 agar (Oxoid Ltd., Cambridge, England) and the plates were incubated in aerobically incubation at $37^{\circ} \mathrm{C}$ for $72 \mathrm{~h}$ according to Torriani et al., (1996), whereas acidified MRS (pH 5.2) agar (Oxoid Ltd., UK) was used for enumeration L. delbrueckii ssp. bulgaricus and anaerobically incubation using AnaeroGen ${ }^{\mathrm{TM}}$ Gas-Pack system in plastic anaerobic jars (Oxoid Ltd., UK) at $43^{\circ} \mathrm{C}$ for $72 \mathrm{~h}$ according to Dave and Shah, (1997). All samples were done in duplicate and 
the colonies were counted after the incubation period and reported in $\left(\log ^{10} \mathrm{CFU} / \mathrm{ml}\right)$.

\section{Rheological measurements}

Apparent viscosities $\eta$ (cp) was measured in triplicates on the cup at $4^{\circ} \mathrm{C}$ with a Brookfield viscometer (model DV II+ Pro Brookfield Engineering Laboratories, Inc., Middleboro, MA) by using a spindle (No.4) rotation of $60 \mathrm{rpm}$ as described by Shihata and Shah, (2002). The Susceptibility to syneresis (STS) was measured by the drainage method according to Isanga and Zhang (2009). The quantity of whey expelled from a $100 \mathrm{~g}$ fermented sample after $6 \mathrm{~h}$ of drainage at $4 \pm 1{ }^{\circ} \mathrm{C}$ was expressed as milliliters of drained whey. The following formula was used to calculate STS $(\%)=(\mathrm{W} 1 / \mathrm{W} 2) \times 100$ Where: $\mathrm{W} 1=$ Volume of whey after drainage; W2=Volume of the sample.

\section{Organoleptic properties}

To judge the quality of the fermented camel milk product based on sensory tests, the product was evaluated by a test panel of seven staff members. Panelists were asked to evaluate each fermented camel milk sample for the following attributes: Appearance 10, flavour 45, body and texture 35 and acidity 10 and overall 100 points, respectively. The maximum score for properties was examined 100 points as described by Farag et al., (2007).

\section{Statistical analysis}

Data from the physicochemical composition, microbiological count and organoleptic properties were subjected to analysis of variance one-way (ANOVA) with a $95 \%$ confidence level to test the differences between all types of fermented camel milk at each sampling time. The SPSS software was performed using the SPSS V.20 (Chicago, II 60611, USA, 2012).

\section{RESULTS AND DISCUSSION}

\section{Fermentation time}

The fermentation time to achieve $\mathrm{pH} 4.60$ in all fermented camel milk generally ranged from 279 to $452.5 \mathrm{~min}$ (Table 1). In general, there was a significant $(P<0.05)$

Table 1: Effect of lactose-hydrolyzed on the fermentation time of fermented camel milk

\begin{tabular}{lcl}
\hline Treatments & $\begin{array}{c}\text { Fermentation } \\
\text { time }(\mathbf{m i n})\end{array}$ & $\begin{array}{l}\text { The visual } \\
\text { appearance of curd } \\
\text { formation }\end{array}$ \\
\hline Control & 452.5 & Simi clotted \\
LHM 25\% & 376.0 & Simi clotted \\
LHM 50\% & 351.0 & Simi clotted \\
LHM 90\% & 286.0 & Clotted \\
Co-hydrolyzed & 279.0 & Clotted \\
\hline
\end{tabular}

The values shown are means of two replicates. LHM=Lactose hydrolyzed before fermentation at percentage 25,50 and $90 \%$ respectively.

Co-hydrolyzed=Lactose hydrolysis and fermentation simultaneously. decrease in fermentation time with an increase in the degree of lactose hydrolysis. Moreover, fermented camel milk made with co-hydrolysis or LHM 90\% treatments showed a higher decreased in the fermentation time about a halftime when compared to the control.

The results revealed that the lowest significant $(P<0.05)$ decrease in fermentation time in co-hydrolysis fermented camel milk treatment ( $279 \mathrm{~min}$ ) may be due to a continuous lactose hydrolysis that took place simultaneously during fermentation, resulting in a moderate level of easily fermentable sugar which gives a faster growth of starter culture and reducing in processing time. Similarly, Schmidt et al., (2016) used the co-hydrolysis milk in yogurt manufacture and observed higher decreases in the fermentation time than control. In addition, Nagaraj et al., (2009), Venica et al., (2014) and Schmidt et al., (2016) used lactose hydrolysis milk in yoghurt manufacture and found decreased in fermentation time by $30-40$ min and they attributed that to the faster fermentation of glucose than lactose in milk.

Moreover, the results showed that with increases in the degree of lactose hydrolysis to $90 \%$ the fermentation time was decreased to $286 \mathrm{~min}$ and it's very closely to the co-hydrolysis treatment. In contrast, increasing the lactose hydrolysis from 25 to $50 \%$ in milk had a little effect on the shortening of the fermentation time. These differences may be attributed to the different ability of starter cultures to utilization of the higher quantity of glucose and galactose present in LHM $90 \%$ than in LHM 25 or $50 \%$ treatments and also the extent resistance of starter cultures to antimicrobial growth-inhibitor present in camel milk.

On the other hand, the control treatment had a higher fermentation time $452.5 \mathrm{~min}$. As well known, the conversion of lactose content to acid in control fermented camel milk only depended on the activity and growth rate of starter cultures. Al Haj and Al Kanhal, (2010) and Mortada and Omer, (2013) proved that the fermentation of camel milk with lactic acid cultures required long time (16-18h) of incubation to coagulation, this referred to the presence of a greater content of antimicrobial growthinhibitor compounds in camel milk which slow the rate of fermentation by lactic acid bacteria.

Furthermore, the visual appearance of fermented camel milk made with co-hydrolysis or LHM 90\% treatments had a real curd produced while; the curd in control or LHM $25 \%$ and $50 \%$ seemed to be poor clotting, watery, with no curd formation.

\section{Viable cell counts}

Globally, the most effective treatments on the growth rate of both S. thermophilus and L. delbrueckii ssp. bulgaricus during 
fermentation and storage period were the co-hydrolysis and LHM 90\% treatments (Table 2). Additionally, increasing the degree of milk lactose hydrolysis also enhanced the growth rate of these bacteria; where highest growth was detected in LHM 90\% samples. Nevertheless, the fermented milk made with LHM 25\% did not appear to influence on the growth or viability of these strains when compared with conventional fermentation.

During the fermentation period, a very marked increase in the viable population of $S$. thermophilus and $L$. delbrueckii ssp. bulgaricus was observed during the first 6 and $8 \mathrm{~h}$ of processing time, respectively, about 1 log cycle higher in each of the co-hydrolysis and LHM 90\% treatments when compared to control or other hydrolyzed lactose treatments.

During $7 \mathrm{~d}$ of refrigerated storage period, the viable population of $S$. thermophilus reached its maximum in the co-hydrolysis, LHM 25, 50 and $90 \%$ treatments $(8.12 \pm 0.12$, $6.95 \pm 0.01,7.98 \pm 0.03$ and $\left.7.99 \pm 0.01 \log _{10} \mathrm{CFU} / \mathrm{ml}\right)$ respectively, while the highest viable population of control treatment was shown during the 14 days of the refrigerated storage $\left(6.98 \pm 0.03 \log _{10} \mathrm{CFU} / \mathrm{ml}\right)$. Thereafter there was a slight decline in the counts in all samples until the end of refrigerated storage. Guler-Akin and Akin, (2007) and Ranadheera et al., (2012) noticed that $S$. thermophilus count increased slowly during refrigerated storage of up to one week, followed by a later decreased by about one log cycle in goat's and cow milk yogurt.
By comparison, the co-hydrolysis and LHM 90\% samples showed significantly higher counts of $L$. delbrueckii ssp. bulgaricus and reached its maximum increment during the $14 \mathrm{~d}$ of the refrigerated storage period $(8.53 \pm 0.09$ and $\left.8.48 \pm 0.16 \log _{10} \mathrm{CFU} / \mathrm{ml}\right)$, respectively, compared to control, LHM 25 and 50\% samples $(7.30 \pm 0.01,7.51 \pm 0.27$ and $\left.7.64 \pm 0.45 \log _{10} \mathrm{CFU} / \mathrm{ml}\right)$, respectively. All samples were shown a slow decline in storage up to 21 days of the storage period. Similarly, Vinderola et al., (2000) and Shori and Baba (2012) found a significant decreased in the viable counts of $L$. delbrueckii subsp. bulgaricus from 7 to $6 \log 10 \mathrm{CFU} / \mathrm{ml}$ in yogurt during the 14 days of the refrigerated storage time.

Furthermore, the results indicated that both of $S$. thermophilus and L. delbrueckii ssp. bulgaricus seems to prefer the simultaneous presence of glucose and lactose (achieved during co-hydrolysis treatments) to enhance the growth of these bacteria this might be attributed to moderate levels of lactose-hydrolyzed until the end of the process, that provide a more readily available free energy source, lead to faster growth and more acid production in fermented products. Schmidt et al., (2016) reported that the higher availability of glucose percentage by the continual activity of $\beta$-galactosidase during the manufacture would further create suitable conditions to enhance the growth of $S$. thermophilus and $L$. delbrueckii ssp. bulgaricus.

Table 2: Effect of lactose hydrolysis on the viable count changes $\left(\log _{10} \mathrm{CFU} / \mathrm{ml}\right)$ of the starter cultures of fermented camel milk during manufacture and storage period for 21 days at $4 \pm 1^{\circ} \mathrm{C}$

\begin{tabular}{|c|c|c|c|c|c|}
\hline \multirow{3}{*}{$\begin{array}{l}\text { Manufacture and Storage } \\
\text { times }\end{array}$} & \multirow[t]{2}{*}{ Control } & \multirow[t]{2}{*}{ Co-hydrolysis } & \multicolumn{3}{|c|}{ The degree of lactose hydrolysis } \\
\hline & & & LHM $25 \%$ & LHM $50 \%$ & LHM $90 \%$ \\
\hline & \multicolumn{5}{|c|}{ Streptococcus thermophilus } \\
\hline 0 hours & $6.16^{\mathrm{cdA}} \pm 0.64$ & $6.20^{\mathrm{dA}} \pm 0.28$ & $6.18^{\mathrm{CA}} \pm 0.59$ & $6.13^{\mathrm{dA}} \pm 0.07$ & $6.15^{\mathrm{fA}} \pm 0.01$ \\
\hline $2 \mathrm{~h}$ & $6.00^{\mathrm{dc}} \pm 0.01$ & $6.77^{\mathrm{CA}} \pm 0.10$ & $6.27^{\mathrm{bcA}} \pm 0.02$ & $6.78^{\mathrm{cdA}} \pm 0.01$ & $6.80^{\mathrm{eB}} \pm 0.06$ \\
\hline $4 \mathrm{~h}$ & $6.30^{\mathrm{bcdD}} \pm 0.01$ & $7.90^{\mathrm{bA}} \pm 0.08$ & $6.44^{\mathrm{abcc}} \pm 0.06$ & $7.02^{\mathrm{bcB}} \pm 0.03$ & $7.88^{\mathrm{bcA}} \pm 0.04$ \\
\hline $6 \mathrm{~h}$ & $6.75^{\mathrm{abc}} \pm 0.21$ & $7.95^{\mathrm{aA}} \pm 0.01$ & $6.52^{\mathrm{abcc}} \pm 0.11$ & $7.49^{\mathrm{abcB}} \pm 0.30$ & $7.94^{\mathrm{abcAB}} \pm 0.08$ \\
\hline $8 \mathrm{~h}$ & $6.83^{\mathrm{abB}} \pm 0.18$ & $7.97^{\mathrm{aA}} \pm 0.01$ & $6.80^{\mathrm{abB}} \pm 0.28$ & $7.65^{\mathrm{abA}} \pm 0.49$ & $7.95^{\mathrm{abA}} \pm 0.01$ \\
\hline 1 day & $6.84^{\mathrm{abB}} \pm 0.09$ & $8.02^{\mathrm{aA}} \pm 0.03$ & $6.81^{\mathrm{abB}} \pm 0.05$ & $7.75^{\mathrm{abA}} \pm 0.21$ & $7.98^{\mathrm{aA}} \pm 0.03$ \\
\hline $7 d$ & $6.91^{\mathrm{aB}} \pm 0.01$ & $8.12^{\mathrm{aA}} \pm 0.12$ & $6.95^{\mathrm{aB}} \pm 0.01$ & $7.98^{\mathrm{aA}} \pm 0.03$ & $7.99^{\mathrm{aA}} \pm 0.01$ \\
\hline $14 d$ & $6.98^{\mathrm{aBC}} \pm 0.03$ & $7.91^{\mathrm{aA}} \pm 0.01$ & $6.74^{\mathrm{abc}} \pm 0.06$ & $7.50^{\mathrm{abcAB}} \pm 0.49$ & $7.85^{\mathrm{cA}} \pm 0.01$ \\
\hline \multirow[t]{2}{*}{$21 d$} & $6.66^{\mathrm{abcB}} \pm 0.07$ & $7.53^{\mathrm{aA}} \pm 0.16$ & $6.65^{\mathrm{abcB}} \pm 0.07$ & $7.43^{\mathrm{abcA}} \pm 0.39$ & $7.49^{\mathrm{dA}} \pm 0.04$ \\
\hline & \multicolumn{5}{|c|}{ Lactobacillus delbrueckii ssp. bulgaricus } \\
\hline 0 hours & $6.04^{\mathrm{CA}} \pm 0.01$ & $6.15^{\mathrm{dA}} \pm 0.11$ & $6.15^{\mathrm{eA}} \pm 0.11$ & $6.08^{\mathrm{eA}} \pm 0.01$ & $6.04^{\mathrm{fA}} \pm 0.01$ \\
\hline $2 \mathrm{~h}$ & $6.07^{\mathrm{CD}} \pm 0.10$ & $7.23^{\mathrm{cA}} \pm 0.04$ & $6.37^{\mathrm{eC}} \pm 0.09$ & $6.41^{\mathrm{dec}} \pm 0.05$ & $7.02^{\mathrm{eB}} \pm 0.03$ \\
\hline $4 \mathrm{~h}$ & $6.48^{\mathrm{bD}} \pm 0.01$ & $7.96^{\mathrm{bA}} \pm 0.01$ & $6.60^{\mathrm{deCD}} \pm 0.01$ & $6.77^{\mathrm{cdc}} \pm 0.16$ & $7.72^{\mathrm{dB}} \pm 0.02$ \\
\hline $6 \mathrm{~h}$ & $6.50^{\mathrm{bC}} \pm 0.04$ & $7.98^{\mathrm{bA}} \pm 0.03$ & $6.68^{\mathrm{cdeBC}} \pm 0.24$ & $6.84^{\mathrm{cdB}} \pm 0.08$ & $7.93^{\mathrm{cdA}} \pm 0.04$ \\
\hline $8 \mathrm{~h}$ & $6.62^{\mathrm{bC}} \pm 0.20$ & $8.45^{\mathrm{aA}} \pm 0.05$ & $6.90^{\mathrm{bcdBC}} \pm 0.14$ & $6.94^{\mathrm{bcB}} \pm 0.06$ & $8.31^{\mathrm{abA}} \pm 0.02$ \\
\hline 1 day & $7.22^{\mathrm{aB}} \pm 0.11$ & $8.46^{\mathrm{aA}} \pm 0.15$ & $7.35^{\mathrm{abB}} \pm 0.49$ & $7.47^{\mathrm{aB}} \pm 0.24$ & $8.38^{\mathrm{abA}} \pm 0.14$ \\
\hline $7 d$ & $7.29^{a c} \pm 0.02$ & $8.48^{\mathrm{aA}} \pm 0.02$ & $7.47^{\mathrm{aBC}} \pm 0.01$ & $7.51^{\mathrm{aB}} \pm 0.11$ & $8.39^{\mathrm{abA}} \pm 0.12$ \\
\hline $14 d$ & $7.30^{\mathrm{aB}} \pm 0.01$ & $8.53^{\mathrm{aA}} \pm 0.09$ & $7.51^{\mathrm{aB}} \pm 0.27$ & $7.64^{\mathrm{aB}} \pm 0.45$ & $8.48^{\mathrm{aA}} \pm 0.16$ \\
\hline $21 d$ & $7.28^{\mathrm{aB}} \pm 0.04$ & $8.44^{\mathrm{aA}} \pm 0.23$ & $7.16^{\mathrm{abcB}} \pm 0.14$ & $7.30^{\mathrm{abB}} \pm 0.01$ & $8.14^{\mathrm{bcA}} \pm 0.20$ \\
\hline
\end{tabular}

${ }^{a b c}$ Different letters in the same row indicates significant difference $(P<0.05)$ among the samples. ${ }^{A B C}$ Different letters in the same column indicates significant difference $(P<0.05)$ among the samples. LHM=Lactose hydrolyzed before fermentation at percentage 25,50 and $90 \%$ respectively. Co-hydrolyzed=Lactose hydrolysis and fermentation simultaneously. 
On the other hand, camel's milk is usually described to be difficult to process into fermented milk due to the problems associated with the lower growth rate of starter cultures, resulting in the longest of fermentation time and lower in the acidity development rate which induced many quality problems in the final product. Hashim et al., (2009), Rahman et al., (2009) and Al Haj and Al Kanhal, (2010) reported that, fermented camel milk failed to reach a gel-like structure (typically of cow milk) after $18 \mathrm{~h}$ of incubation. This can be attributed to the presence of higher concentrations of natural growth-inhibiting factors in the camel milk.

\section{$\mathrm{pH}$ values and Titratable acidity}

During the fermentation period the mean values of $\mathrm{pH}$ were a highly significant $(P<0.05)$ dropped in the cohydrolysis and LHM $90 \%$ samples as the fermentation hour was increased, and reached to $4.62 \pm 0.01$ and $4.62 \pm 0.01$, in 6 hours of the fermentation period, respectively, whereas the control, LHM 25 and 50\% samples reached to the near of the same degree of $\mathrm{pH}$ in 8 hours of the fermentation process it was found to be $4.68 \pm 0.05,4.62 \pm 0.02$ and $4.64 \pm 0.02$, respectively (Table 3).

The higher decreased in the $\mathrm{pH}$ values in the co-hydrolysis fermented camel milk than other treatments may be due to the gradual conversion of a suitable quantity of glucose after inoculation that provides the optimal conditions for rapid growth of starter cultures and more acid production immediately during the first few hours of incubation than other treatments. These observations were similar to those observed by Ismail et al., (1983) and Vénica et al., (2014) who noticed a higher decrease in $\mathrm{pH}$ value in lactose hydrolyzed yogurt production in the presence of $\beta$-galactosidase than control and that attributed to continual activity of $\beta$-galactosidase to the conversion of a greater percentage of the free energy source (glucose) consumed and metabolized to acid by starter culture organisms.

Table 3: Effect of lactose-hydrolyzed on the changes of $\mathrm{pH}$ values, titratable acidity $\%$ and lactose concentration $\%$ in fermented camel milk during manufacture and storage period for 21 days at $4 \pm 1^{\circ} \mathrm{C}$

\begin{tabular}{|c|c|c|c|c|c|}
\hline \multirow{3}{*}{$\begin{array}{l}\text { Manufacture and Storage } \\
\text { times }\end{array}$} & \multirow[t]{2}{*}{ Control } & \multirow[t]{2}{*}{ Co-hydrolysis } & \multicolumn{3}{|c|}{ The degree of lactose hydrolysis } \\
\hline & & & LHM $25 \%$ & LHM $25 \%$ & LHM $25 \%$ \\
\hline & \multicolumn{5}{|c|}{$\mathrm{pH}$ values } \\
\hline 0 hours & $6.71^{\mathrm{aA}} \pm 0.03$ & $6.70^{\mathrm{aA}} \pm 0.01$ & $6.66^{\mathrm{aA}} \pm 0.06$ & $6.69^{\mathrm{aA}} \pm 0.02$ & $6.68^{\mathrm{aA}} \pm 0.04$ \\
\hline $2 \mathrm{~h}$ & $6.25^{\mathrm{bA}} \pm 0.07$ & $5.95^{\mathrm{bC}} \pm 0.07$ & $6.20^{\mathrm{bAB}} \pm 0.01$ & $6.15^{\mathrm{bAB}} \pm 0.07$ & $6.05^{\mathrm{bBC}} \pm 0.07$ \\
\hline $4 \mathrm{~h}$ & $5.75^{\mathrm{cA}} \pm 0.07$ & $5.15^{\mathrm{cB}} \pm 0.07$ & $5.45^{\mathrm{CAB}} \pm 0.07$ & $5.60^{\mathrm{cA}} \pm 0.28$ & $5.15^{\mathrm{cB}} \pm 0.07$ \\
\hline $6 \mathrm{~h}$ & $5.15^{\mathrm{dA}} \pm 0.07$ & $4.62^{\mathrm{dB}} \pm 0.01$ & $5.10^{\mathrm{dA}} \pm 0.01$ & $5.05^{\mathrm{dA}} \pm 0.07$ & $4.62^{\mathrm{dB}} \pm 0.01$ \\
\hline $8 \mathrm{~h}$ & $4.68^{\mathrm{eA}} \pm 0.05$ & $4.55^{\mathrm{deB}} \pm 0.07$ & $4.62^{\mathrm{eAB}} \pm 0.02$ & $4.64^{\mathrm{eAB}} \pm 0.02$ & $4.60^{\mathrm{de} A \mathrm{~B}} \pm 0.01$ \\
\hline 1 day & $4.62^{\mathrm{eA}} \pm 0.01$ & $4.55^{\mathrm{deA}} \pm 0.07$ & $4.58^{\mathrm{efA}} \pm 0.01$ & $4.55^{\mathrm{eA}} \pm 0.07$ & $4.55^{\mathrm{deA}} \pm 0.07$ \\
\hline $7 d$ & $4.60^{\mathrm{efA}} \pm 0.01$ & $4.50^{\mathrm{dec}} \pm 0.01$ & $4.57^{\mathrm{efAB}} \pm 0.01$ & $4.54^{\mathrm{eBC}} \pm 0.01$ & $4.53^{\mathrm{deBC}} \pm 0.04$ \\
\hline $14 d$ & $4.58^{\mathrm{efA}} \pm 0.04$ & $4.57^{\mathrm{deA}} \pm 0.02$ & $4.53^{\mathrm{efAB}} \pm 0.04$ & $4.56^{\mathrm{eAB}} \pm 0.01$ & $4.49^{e \mathrm{~B}} \pm 0.01$ \\
\hline \multirow[t]{2}{*}{$21 d$} & $4.50^{f A} \pm 0.01$ & $4.45^{\mathrm{eA}} \pm 0.07$ & $4.50^{\mathrm{fA}} \pm 0.01$ & $4.54^{\mathrm{eA}} \pm 0.02$ & $4.50^{\mathrm{eA}} \pm 0.01$ \\
\hline & \multicolumn{5}{|c|}{ Titratable acidity \% } \\
\hline 0 hours & $0.18^{\mathrm{hA}} \pm 0.01$ & $0.18^{\mathrm{fAB}} \pm 0.01$ & $0.18^{\mathrm{hB}} \pm 0.01$ & $0.18^{\mathrm{hAB}} \pm 0.01$ & $0.18^{\mathrm{fB}} \pm 0.01$ \\
\hline $2 \mathrm{~h}$ & $0.30^{g \mathrm{C}} \pm 0.01$ & $0.35^{\mathrm{eB}} \pm 0.01$ & $0.41^{\mathrm{gA}} \pm 0.01$ & $0.35^{\mathrm{gB}} \pm 0.01$ & $0.40^{\mathrm{eA}} \pm 0.01$ \\
\hline $4 \mathrm{~h}$ & $0.42^{\mathrm{fC}} \pm 0.01$ & $0.54^{\mathrm{dA}} \pm 0.04$ & $0.48^{\mathrm{fB}} \pm 0.01$ & $0.48^{\mathrm{fB}} \pm 0.01$ & $0.55^{\mathrm{dA}} \pm 0.01$ \\
\hline $6 \mathrm{~h}$ & $0.53^{\mathrm{eD}} \pm 0.01$ & $0.75^{\mathrm{CA}} \pm 0.01$ & $0.56^{\mathrm{eC}} \pm 0.01$ & $0.61^{\mathrm{eB}} \pm 0.01$ & $0.77^{\mathrm{CA}} \pm 0.01$ \\
\hline $8 \mathrm{~h}$ & $0.72^{\mathrm{dB}} \pm 0.02$ & $0.81^{\mathrm{bA}} \pm 0.01$ & $0.75^{\mathrm{dB}} \pm 0.01$ & $0.74^{\mathrm{dB}} \pm 0.01$ & $0.80^{\mathrm{bcA}} \pm 0.01$ \\
\hline 1 day & $0.78^{\mathrm{CB}} \pm 0.01$ & $0.81^{\mathrm{bA}} \pm 0.01$ & $0.78^{\mathrm{cB}} \pm 0.01$ & $0.78^{\mathrm{CB}} \pm 0.01$ & $0.80 b^{C A B} \pm 0.01$ \\
\hline $7 d$ & $0.81^{\mathrm{bA}} \pm 0.01$ & $0.83^{\mathrm{bA}} \pm 0.01$ & $0.79^{\mathrm{bcA}} \pm 0.01$ & $0.80^{\mathrm{bA}} \pm 0.01$ & $0.80^{\mathrm{bA}} \pm 0.03$ \\
\hline $14 d$ & $0.83^{\mathrm{aA}} \pm 0.01$ & $0.84^{\mathrm{abA}} \pm 0.01$ & $0.81^{\mathrm{abB}} \pm 0.01$ & $0.81^{\mathrm{bB}} \pm 0.01$ & $0.82^{\mathrm{bAB}} \pm 0.01$ \\
\hline \multirow[t]{2}{*}{$21 \mathrm{~d}$} & $0.83^{\mathrm{aBC}} \pm 0.01$ & $0.87^{\mathrm{aA}} \pm 0.01$ & $0.83^{\mathrm{ac}} \pm 0.02$ & $0.84^{\mathrm{aABC}} \pm 0.01$ & $0.86^{\mathrm{aAB}} \pm 0.01$ \\
\hline & \multicolumn{5}{|c|}{ Lactose $\%$} \\
\hline $\mathrm{Oh}$ & $4.47^{\mathrm{aA}} \pm 0.14$ & $4.44^{\mathrm{aA}} \pm 0.01$ & $3.40^{\mathrm{aB}} \pm 0.17$ & $2.21^{\mathrm{aC}} \pm 0.03$ & $0.40^{\mathrm{aD}} \pm 0.05$ \\
\hline $2 \mathrm{~h}$ & $4.05^{\mathrm{bA}} \pm 0.16$ & $2.33^{\mathrm{bB}} \pm 0.15$ & $2.42^{\mathrm{bB}} \pm 0.04$ & $1.99^{\mathrm{bc}} \pm 0.01$ & $0.34^{\mathrm{abD}} \pm 0.05$ \\
\hline $4 \mathrm{~h}$ & $3.78^{\mathrm{cA}} \pm 0.15$ & $1.61^{\mathrm{CD}} \pm 0.04$ & $2.34^{\mathrm{bcB}} \pm 0.02$ & $1.93^{\mathrm{bcc}} \pm 0.04$ & $0.33^{\mathrm{ab} \mathrm{E}_{ \pm} 0.04}$ \\
\hline $6 \mathrm{~h}$ & $3.36^{\mathrm{cA}} \pm 0.12$ & $1.46^{\mathrm{dD}} \pm 0.02$ & $2.28^{\mathrm{bcB}} \pm 0.10$ & $1.92^{\mathrm{bcc}} \pm 0.06$ & $0.33^{\mathrm{ab}} \pm 0.04$ \\
\hline $8 \mathrm{~h}$ & $3.26^{\mathrm{dA}} \pm 0.02$ & $1.28^{\mathrm{deD}} \pm 0.09$ & $2.28^{\mathrm{bcB}} \pm 0.06$ & $1.87^{\mathrm{bcdc}} \pm 0.04$ & $0.32^{\mathrm{abE}} \pm 0.04$ \\
\hline $1 d$ & $3.15^{\mathrm{dA}} \pm 0.01$ & $1.23^{\text {def } D} \pm 0.03$ & $2.25^{\mathrm{bcB}} \pm 0.07$ & $1.82^{\mathrm{cdc}} \pm 0.03$ & $0.32^{\mathrm{bE}} \pm 0.00$ \\
\hline $7 d$ & $3.04^{\mathrm{dA}} \pm 0.08$ & $1.21^{\mathrm{efD}} \pm 0.01$ & $2.25^{\mathrm{bcB}} \pm 0.07$ & $1.80^{\mathrm{cdC}} \pm 0.07$ & $0.31^{\mathrm{bE}} \pm 0.00$ \\
\hline $14 d$ & $3.00^{\mathrm{dA}} \pm 0.00$ & $1.20^{\mathrm{fD}} \pm 0.00$ & $2.25^{\mathrm{bcB}} \pm 0.07$ & $1.78^{\mathrm{dC}} \pm 0.11$ & $0.31^{\mathrm{bE}} \pm 0.00$ \\
\hline $21 d$ & $2.95^{\mathrm{dA}} \pm 0.07$ & $1.16^{\mathrm{tD}} \pm 0.08$ & $2.20^{\mathrm{cB}} \pm 0.00$ & $1.75^{\mathrm{dC}} \pm 0.07$ & $0.30^{\mathrm{b}} \pm 0.01$ \\
\hline
\end{tabular}

${ }^{a b c}$ Different letters in the same row indicates significant difference $(P<0.05)$ among the samples. ${ }^{A B C}$ Different letters in the same column indicates significant difference $(P<0.05)$ among the samples. LHM=Lactose hydrolyzed before fermentation at percentage 25,50 and $90 \%$ respectively. Co-hydrolyzed=Lactose hydrolysis and fermentation simultaneously. 
Moreover, the values of $\mathrm{pH}$ obtained from LHM 25\% samples was not significantly $(P<0.05)$ different than in control fermented camel milk and the rate of the changes in the $\mathrm{pH}$ level observed to be slowly decreased at the beginning, and steadily declined during the fermentation process until the end of the $3^{\text {rd }}$ week of refrigerated storage. This might be attributed to a limited amount of free energy source in camel milk medium or also, might be due to the presence of antimicrobial agents in camel milk, which caused the lower growth of the microorganisms (Attia et al., 2001; Rahman et al., 2009).

After one day of refrigerated storage period, the mean values of $\mathrm{pH}$ in control and lactose hydrolysis fermented camel milk samples decreased slightly at the end of the $2^{\text {nd }}$ week ( $3^{\text {rd }}$ reading). This could be attributed to the activity of microorganisms at cold storage temperatures (Dave and Shah, 1997; Vénica et al., 2013 and 2014).

On the other hand, as it was expected, the increase in the acidity for all fermented camel milk samples showed an opposite trend to $\mathrm{pH}$ values. It was observed that, at the end of fermentation period ( $8 \mathrm{~h}$ ), the co-hydrolysis fermented camel milk had a higher significant $(P<0.05)$ acidity \% $(0.81 \pm 0.01)$. The LHM $90 \%$ samples had nearly the same acidity: $0.80 \pm 0.01$, whilst the control, LHM 25 and 50\% samples had the lowest acidity, $0.72 \pm 0.02,0.75 \pm 0.01$ and $0.74 \pm 0.01 \%$, respectively, which is attributed to poor ability of yogurt bacteria culture to grow in this condition medium and utilization of glucose and lactose present in LHM 25 or $50 \%$ treatment to produce acidity.

Moreover, with an increasing degree of lactose hydrolysis in fermented camel milk samples, the resulted acidity correspondingly increased. This result can be explained by previous studies explored that the high content of antimicrobial activity could affect the growth of bacteria casing camel milk to be resistant to fermentation (Hashim et al., 2009;(Rahman et al., 2009).

A slight increased in acidity was observed at the beginning of the storage for all fermented camel milk with little significant $(P<0.05)$ differences among samples. However, the acidity $\%$ production in the co-hydrolysis fermented camel milk $(0.87 \pm 0.01)$ was significantly higher $(P<0.05)$. LHM $90 \%$ showed almost the same acidity $(0.86 \pm 0.01)$, whilst the control, LHM 25 and 50\% samples had the lowest acidity $\%, 0.83 \pm 0.01,0.83 \pm 0.02$ and $0.84 \pm 0.01 \%$, respectively. This might be attributed to the activity of starter cultures. Similarly, Ismail et al., (1983) and Nagaraj et al., (2009) reported a slight increase in titratable acidity for all hydrolyzed experimental yogurts in comparison to control at the end of storage period.

\section{Lactose concentration}

In general, the lactose hydrolysis percentages in control and experimental fermented camel milk decreased, but the important higher significant $(P<0.05)$ decreasing in the lactose content occurred in the co-hydrolysis fermented camel milk during the fermentation process compared to other treatments. At the end of the manufacturing time $(8 \mathrm{~h})$ the highest significant $(P<0.05)$ lactose conversion rate was observed in the co-hydrolysis samples, the initial lactose values decreasing from $4.44 \pm 0.01$ to $1.28 \pm 0.09$ (approximately $71.25 \%$ ). This decreased was produced mainly by the inclusion of $\beta$-galactosidase enzyme and, by the metabolic activity of the starter. Ismail et al., (1983) and Toba et al., (1986) reported that yogurts which produced through the simultaneous addition of $\beta$-galactosidase with the starter culture achieved a conversion of up to $64-85 \%$ of initial lactose concentration at the end of $8 \mathrm{~h}$ process.

On the contrary, the changes in the lactose concentration during the fermentation of control samples were relatively mild and very slowly; the initial lactose values decreased from $4.47 \pm 0.14$ to $3.26 \pm 0.02$ (approximately $27 \%$ ) at the end of $8 \mathrm{~h}$ of the manufacturing process. As well known, the decrease in the lactose content in control samples was produced only by the activity of starter cultures. These results are similar to those obtained by Martins et al., (2012) and Wolf et al., (2015) who reported that only a part of the lactose $(\sim 20-30 \%)$ is metabolized in traditional yogurts during manufacture.

Moreover, the lactose concentration in LHM 25, 50 and $90 \%$ samples decreased to approximately 32.7, 15.5 and $19.5 \%$ of the initial lactose, respectively. Several researchers reported that the higher concentration of galactose and glucose in hydrolyzed fermented milk could inhibit microbial utilization of other carbon sources (lactose) and this phenomenon is referred to as catabolized inhibition (Vénica et al., 2013).

However, the maximum significant $(\mathrm{P}<0.05)$ degree of lactose hydrolysis in all experimental fermented camel occurred in the first 2-4 h of fermentation process, while in control treatment the lactose hydrolysis gradually decreased, reaching a maximum during $8 \mathrm{~h}$ of the fermentation period. These results can be attributed to the inactivation of the activity of $\beta$-galactosidase enzyme at lower $\mathrm{pH}$ values. Lin et al., (1989) noticed that the acidity produced by the starter cultures reduces the $\beta$-galactosidase activity gradually, and over $95 \%$ of $\beta$-galactosidase activity was inactivated after $4 \mathrm{~h}$ of fermentation process at $\mathrm{pH}$ 5.0. Thus, 4-6 hours could be considered as optimal for incubation fermented camel milk.

In addition, the control and all experimental fermented camel milk decreased steadily and remained practically 
constant without significant changes until the end of the refrigerated storage period. Vénica et al., (2013) observed no significant changes in lactose hydrolysis percentages during storage for 21 days at $5^{\circ} \mathrm{C}$ for natural and lactose hydrolysis yogurts.

\section{The quantity of EPS}

Globally, the amount of EPS produced during the storage in all fermented camel milk treatments was ranged between $133.7 \pm 2.3$ to $247.3 \pm 2.1 \mathrm{mg} / \mathrm{kg}$ (Table 4 ). These results agreed with that finding by Ruas-Madiedo and Zoon, (2003) and Ibrahim, (2015b) who indicated that the quantity of EPS produced ranged from 50 to $\sim 450 \mathrm{mg} / \mathrm{L}$ in fermented milk, depending on the LAB cultures applied and fermentation conditions. Moreover, an increase in the degree of lactose hydrolysis resulted in the increase in the amount of EPS produced. These results agreed with that reported by Mozzi et al., (2001), Degeest et al., (2002) and De Vin et al., (2005) who found that the starters have different preferences for the carbohydrate source. The type of carbon source apparently governs the total amount of EPS synthesized during fermentation.

During the storage period, the amount of EPS produced increased gradually to the maximum in all treatments up the first 14 days followed by a slight decrease at the end of the storage period with significant $(P<0.05)$ different among treatments. Deegest et al., (2002) and Ibrahim, (2015b) found a significant $(P<0.05)$ reduction of the EPS concentration in all fermented camel milk during the first two weeks of storage. However, in the $2^{\text {nd }}$ week of the storage, the co-hydrolysis fermented camel milk had a higher amount of EPS $(262.3 \pm 2.3 \mathrm{mg} / \mathrm{kg})$ as well as fermented camel milk made with LHM 90\% relatively close to that $(250.3 \pm 5.0 \mathrm{mg} / \mathrm{kg})$, while control, LHM 25 and $50 \%$ had the lowest concentration $(178.3 \pm 0.6,185.3 \pm 5.7$ and $197.7 \pm 2.3 \mathrm{mg} / \mathrm{kg}$, respectively). This result was similar to that reported by De Vuyst et al., (2003), Mende et al., (2013) and Schmidt et al., (2016) who indicated that yogurt made from hydrolyzed and co-hydrolysis milk was higher in the amount of EPS than control. The yield of EPS is often associated with the culture cell number and the concentration of glucose and galactose in milk.

\section{Apparent viscosity}

There was a significant difference $(P<0.05)$ in apparent viscosity among the co-hydrolysis and all experimental fermented samples during the storage period (Table 4). The apparent viscosity was gradually increased during the storage in all treatments and the maximum increased was observed at 14 days, followed by a slight decline until the end of storage. According to Sahan et al., (2008) and Shori et al., (2013) there was an increase in viscosity values over storage time in yogurt and this can be associated with the rearrangement in protein molecular structure.

Furthermore, the highest viscosity values were observed in the co-hydrolysis fermented camel milk (1588.7 \pm 9.0

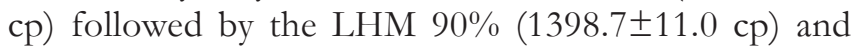
LHM 50\% (1289.7 $\pm 10.5 \mathrm{cp})$ samples, while the lowest was recorded in the LHM 25\% (1084.0土14.2 cp) and control $(1040.3 \pm 4.0 \mathrm{cp})$ samples during the 14 days of storage, respectively. Clearly, the higher amounts of EPS produced with the co-hydrolysis and LHM90\% treatments in our experimental compared to other fermented camel milk treatments caused a concomitant increase in the apparent

Table 4: Effect of lactose-hydrolyzed on the amount of exopolysaccharide and rheological properties of fermented camel milk during the storage period of 21 days at $4 \pm 1^{\circ} \mathrm{C}$

\begin{tabular}{|c|c|c|c|c|c|}
\hline \multirow{3}{*}{$\begin{array}{l}\text { Storage } \\
\text { (Days) }\end{array}$} & \multirow[t]{2}{*}{ Control } & \multirow[t]{2}{*}{ Co-hydrolysis } & \multicolumn{3}{|c|}{ The degree of lactose hydrolysis } \\
\hline & & & LHM $25 \%$ & LHM $25 \%$ & LHM $25 \%$ \\
\hline & \multicolumn{5}{|c|}{ Exopolysaccharide (mg/kg) } \\
\hline 1 & $133.7^{\mathrm{CE}} \pm 2.3$ & $199.0^{\mathrm{dA}} \pm 1.7$ & $145.0^{\mathrm{dD}} \pm 1.0$ & $171.3^{\mathrm{c} C} \pm 3.5$ & $193.0^{\mathrm{dB}} \pm 3.6$ \\
\hline 7 & $153.7^{\mathrm{bc}} \pm 3.5$ & $219.7^{\mathrm{CA}} \pm 5.0$ & $161.3^{\mathrm{cc}} \pm 5.5$ & $180.3^{\mathrm{bcB}} \pm 9.5$ & $216.3^{\mathrm{cA}} \pm 3.2$ \\
\hline 14 & $178.3^{\mathrm{aE}} \pm 0.6$ & $262.3^{\mathrm{aA}} \pm 2.3$ & $185.3^{\mathrm{aD}} \pm 5.7$ & $197.7^{\mathrm{ac}} \pm 2.3$ & $250.3^{\mathrm{aB}} \pm 5.0$ \\
\hline \multirow[t]{2}{*}{21} & $155.3^{\mathrm{bE}} \pm 1.5$ & $247.3^{\mathrm{bA}} \pm 2.1$ & $174.3^{\mathrm{bD}} \pm 5.5$ & $185.3^{\mathrm{bc}} \pm 1.5$ & $236.7^{\mathrm{bB}} \pm 6.4$ \\
\hline & \multicolumn{5}{|c|}{ Apparent Viscosity (cp) } \\
\hline 1 & $928.0^{\mathrm{dD}} \pm 2.6$ & $1274.0^{\mathrm{dA}} \pm 8.7$ & $945.7^{\mathrm{CD}} \pm 9.0$ & $1060.0^{\mathrm{bC}} \pm 52.9$ & $1198.3^{\mathrm{dB}} \pm 7.6$ \\
\hline 7 & $969.7^{\mathrm{cc}} \pm 6.1$ & $1389.3^{\mathrm{cA}} \pm 8.1$ & $984.0^{\mathrm{bC}} \pm 4.4$ & $1246.7^{\mathrm{aB}^{\mathrm{B}}} \pm 45.1$ & $1252.3^{\mathrm{CB}} \pm 12.6$ \\
\hline 14 & $1040.3^{\mathrm{aE}} \pm 4.0$ & $1588.7^{\mathrm{aA}} \pm 9.0$ & $1084.0^{\mathrm{aD}_{ \pm}} \pm 14.2$ & $1289.7^{\mathrm{ac}} \pm 10.5$ & $1398.7^{\mathrm{aB}} \pm 11.0$ \\
\hline \multirow[t]{2}{*}{21} & $983.0^{\mathrm{bD}} \pm 1.7$ & $1507.3^{\mathrm{bA}} \pm 57.0$ & $1005.0^{\mathrm{bD}} \pm 26.5$ & $1253.7^{\mathrm{ac}} \pm 8.5$ & $1354.3^{\mathrm{bB}} \pm 12.5$ \\
\hline & \multicolumn{5}{|c|}{ Susceptibility to syneresis (STS) \% } \\
\hline 1 & $34.5^{\mathrm{aA}} \pm 1.19$ & $26.2^{\mathrm{aD}} \pm 0.76$ & $31.8^{\mathrm{ab}} \pm 0.10$ & $29.3^{\mathrm{ac}} \pm 0.80$ & $27.3^{\mathrm{aD}} \pm 0.26$ \\
\hline 7 & $30.7^{\mathrm{bA}} \pm 0.46$ & $23.0^{\mathrm{bE}} \pm 1.05$ & $28.8^{\mathrm{bB}} \pm 0.74$ & $26.6^{\mathrm{bC}} \pm 0.81$ & $24.7^{\mathrm{bD}} \pm 1.21$ \\
\hline 14 & $28.7^{\mathrm{CA}} \pm 0.58$ & $20.7^{\mathrm{CD}} \pm 1.15$ & $27.5^{\mathrm{CB}} \pm 0.55$ & $23.1^{{ }^{c}} \pm 0.10$ & $21.2^{\mathrm{cD}} \pm 0.29$ \\
\hline 21 & $27.9^{\mathrm{CA}} \pm 0.32$ & $18.9^{c E} \pm 0.85$ & $26.4^{\mathrm{dB}} \pm 0.40$ & $23.7^{\mathrm{C}} \pm 0.44$ & $20.5^{\mathrm{CD}} \pm 0.87$ \\
\hline
\end{tabular}

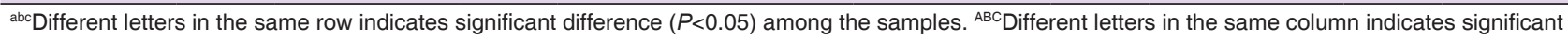
difference $(P<0.05)$ among the samples. LHM=Lactose hydrolyzed before fermentation at percentage 25,50 and $90 \%$ respectively. Co-hydrolyzed=Lactose hydrolysis and fermentation simultaneously. 
viscosity. This difference in viscosity among all fermented milk treatments can be attributed to differences in the amount, branching and molecular mass characteristics of EPS and their ability to interact with milk protein gel which loaded a difference in the intrinsic viscosity (Ruas-Madiedo and Zoon, 2003; Folkenberg et al.,2006; Mende et al., 2013).

\section{Susceptibility to syneresis (STS) \%}

The storage time affected significantly $(P<0.05)$ the STS \% (Table 4). The STS \% decreased gradually for all fermented milk samples over 21 days of the storage period and fluctuated within the range of $18.9 \pm 0.85$ to $27.9 \pm 0.32 \%$. These results were similar to those observed by Ibrahim, (2015b) who reported that the inclusion of EPS-producing starter cultures in the manufacture of fermented camel milk was another approach to overcome the problem of weak body and improving the water holding capacity of the gel which leads to a reduction of STS \% during the storage.

At the end of the storage period, the highest STS \% were observed in control samples $(27.9 \pm 0.32 \%)$ followed by LHM $25 \%$ samples $(26.4 \pm 0.40 \%)$, the lowest STS \% being found in the co-hydrolysis fermented camel milk $(18.9 \pm 0.85 \%)$ followed by LHM 90\% (20.5 $\pm 0.87 \%)$ and LHM 50\% (23.7 $\pm 0.44 \%)$, respectively. According to the previous results, the differences in STS \% among all fermented milk can be attributed to differences in the amount and molecular characteristics of EPS, which act as stabilizers, viscosifying and syneresis-lowering agents due to the better water-holding capacity and that consequent decreases syneresis. Many researchers as Folkenberg et al., (2006), Ramchandran and Shah, (2009) and Shori et al., (2013) found that yogurts made with EPS-producing cultures usually reduce in syneresis by filling the interstices and the channels of the protein matrix, then caused texture improvement.

Our experiment showed weakness in the gel structure of control fermented camel milk that led to the increasing the STS \%. These observations agreed with Al-Zoreky, and Al-Otaibi, (2015) who found that yogurts made from camel milk only without thickeners gelatin had a fragile gel and heterogeneous curd structure.

\section{Sensory evaluation}

The co-hydrolysis fermented camel milk took a higher significant $(P<0.05)$ scores in flavour throughout the storage period compared to control and the other treatments (Table 5). This difference could be attributed to moderate levels and balanced of flavour compounds mainly aroma (acetaldehyde and diacetyl) synthesized during manufacture and storage which may be relative to higher cell counts of L. delbrueckii ssp. bulgaricus. Cheng, (2010) and Venica et al., (2013) observed that yogurts made with the addition of $\beta$-galactosidase caused a significant change in the carbohydrate pattern that can affect on the production of organic and volatile compounds such as lactic, formic acids, acetaldehyde, and diacetyl in fermented products.

Table 5: Effect of lactose-hydrolyzed on the sensory properties of fermented camel milk during the storage period of 21 days at $4 \pm 1^{\circ} \mathrm{C}$

\begin{tabular}{|c|c|c|c|c|c|c|}
\hline \multirow[t]{2}{*}{ Sensory Characteristics } & \multirow{2}{*}{$\begin{array}{c}\text { Storage } \\
\text { (Days) }\end{array}$} & \multirow[t]{2}{*}{ Control } & \multirow[t]{2}{*}{ Co-hydrolysis } & \multicolumn{3}{|c|}{ The degree of lactose hydrolysis } \\
\hline & & & & LHM $25 \%$ & LHM $25 \%$ & LHM $25 \%$ \\
\hline \multirow{4}{*}{$\begin{array}{l}\text { Flavour } \\
\text { (Max } 45 \text { Points) }\end{array}$} & 1 & $29.57^{\mathrm{bc}} \pm 1.51$ & $36.86^{\mathrm{bA}} \pm 1.86$ & $31.86^{\mathrm{abB}} \pm 1.35$ & $33.29^{\mathrm{abB}} \pm 2.93$ & $34.00^{\mathrm{bcB}} \pm 2.38$ \\
\hline & 7 & $32.71^{\mathrm{ac}} \pm 2.56$ & $38.14^{\mathrm{bA}} \pm 2.27$ & $33.43^{\mathrm{aBC}} \pm 1.13$ & $34.86^{\mathrm{aBC}} \pm 2.41$ & $35.57^{\mathrm{abB}} \pm 2.07$ \\
\hline & 14 & $32.29^{\mathrm{aD}} \pm 1.60$ & $39.00^{\mathrm{aA}} \pm 2.00$ & $33.29^{a C D} \pm 2.14$ & $35.71^{\mathrm{aBC}} \pm 2.75$ & $36.43^{\mathrm{aB}} \pm 2.57$ \\
\hline & 21 & $31.43^{\mathrm{abB}} \pm 1.72$ & $34.14^{\mathrm{bA}} \pm 2.04$ & $30.43^{\mathrm{bB}} \pm 1.62$ & $31.29^{\mathrm{bB}} \pm 0.95$ & $32.00^{\mathrm{CB}} \pm 1.00$ \\
\hline \multirow{4}{*}{$\begin{array}{l}\text { Body and texture (Max } \\
\text { 35Points) }\end{array}$} & 1 & $20.71^{\mathrm{aD}} \pm 1.89$ & $28.43^{\mathrm{CA}} \pm 1.51$ & $22.57^{\mathrm{bCD}} \pm 1.72$ & $23.00^{\mathrm{aBC}} \pm 3.27$ & $25.00^{\mathrm{bB}} \pm 0.58$ \\
\hline & 7 & $21.71^{\mathrm{aD}} \pm 1.50$ & $31.29^{\mathrm{abA}} \pm 0.95$ & $23.57^{\mathrm{abc}} \pm 1.51$ & $24.00^{\mathrm{ac}} \pm 1.73$ & $26.71^{\mathrm{abB}} \pm 1.89$ \\
\hline & 14 & $21.86^{\mathrm{aD}} \pm 0.69$ & $32.43^{\mathrm{aA}} \pm 0.53$ & $24.00^{\mathrm{abc}} \pm 1.15$ & $24.29^{\mathrm{aC}} \pm 1.11$ & $28.14^{\mathrm{aB}} \pm 1.77$ \\
\hline & 21 & $21.29^{\mathrm{aD}} \pm 1.38$ & $30.43^{\mathrm{bA}} \pm 1.51$ & $25.29^{\mathrm{ac}} \pm 1.60$ & $25.29^{\mathrm{aC}} \pm 1.60$ & $27.86^{\mathrm{aB}} \pm 2.12$ \\
\hline \multirow{4}{*}{$\begin{array}{l}\text { Appearance and } \\
\text { Colour } \\
\text { (Max } 10 \text { Points) }\end{array}$} & 1 & $6.00^{\mathrm{bC}} \pm 0.58$ & $7.86^{\mathrm{bA}} \pm 0.90$ & $6.14^{\mathrm{bC}} \pm 0.38$ & $6.86^{\mathrm{abB}} \pm 0.38$ & $7.14^{\mathrm{bB}} \pm 0.38$ \\
\hline & 7 & $6.29^{a c} \pm 0.49$ & $8.14^{\mathrm{aA}} \pm 0.69$ & $6.43^{\mathrm{ac}} \pm 0.53$ & $7.14^{\mathrm{aB}} \pm 0.38$ & $7.43^{\mathrm{aB}} \pm 0.79$ \\
\hline & 14 & $6.43^{\mathrm{ac}} \pm 0.79$ & $8.29^{\mathrm{aA}} \pm 0.76$ & $6.71^{\mathrm{aBC}} \pm 1.11$ & $7.29^{\mathrm{aAB}_{ \pm}} \pm 1.25$ & $7.71^{\mathrm{aAB}_{ \pm} 0.76}$ \\
\hline & 21 & $6.14^{\mathrm{bB}} \pm 0.69$ & $7.86^{\mathrm{bA}} \pm 1.07$ & $6.29^{\mathrm{bB}} \pm 0.49$ & $6.29^{\mathrm{bB}} \pm 0.49$ & $7.14^{\mathrm{bA}} \pm 0.69$ \\
\hline \multirow{4}{*}{$\begin{array}{l}\text { Acidity } \\
\text { (Max } 10 \text { Points) }\end{array}$} & 1 & $6.14^{\mathrm{bB}} \pm 0.38$ & $7.86 a^{\mathrm{bA}} \pm 0.90$ & $6.57^{\mathrm{aB}} \pm 0.98$ & $6.71^{\mathrm{aB}} \pm 1.11$ & $6.86^{\mathrm{bB}} \pm 0.38$ \\
\hline & 7 & $6.71^{\mathrm{aB}} \pm 0.49$ & $8.14^{\mathrm{abA}} \pm 0.38$ & $7.00^{\mathrm{aB}} \pm 1.00$ & $7.14^{\mathrm{aB}} \pm 0.69$ & $7.29^{\mathrm{abB}} \pm 0.49$ \\
\hline & 14 & $6.86^{\mathrm{aB}} \pm 0.38$ & $8.29^{\mathrm{aA}} \pm 0.76$ & $7.29^{\mathrm{aB}} \pm 0.49$ & $7.43^{\mathrm{aB}} \pm 0.53$ & $7.57^{\mathrm{aB}} \pm 0.79$ \\
\hline & 21 & $6.43^{\mathrm{abB}} \pm 0.53$ & $7.43^{\mathrm{bA}} \pm 0.53$ & $7.00^{\mathrm{aAB}} \pm 0.58$ & $7.14^{\mathrm{aA}} \pm 0.69$ & $7.14^{\mathrm{abA}} \pm 0.38$ \\
\hline \multirow{4}{*}{$\begin{array}{l}\text { Overall } \\
\text { Acceptability } \\
\text { Score (100 Points) }\end{array}$} & 1 & $62.43^{\mathrm{bD}} \pm 2.07$ & $81.00^{\mathrm{bA}} \pm 2.83$ & $67.14^{\mathrm{bC}} \pm 1.95$ & $69.86^{\mathrm{bBC}} \pm 5.52$ & $73.00^{\mathrm{CB}} \pm 3.11$ \\
\hline & 7 & $67.43^{\mathrm{aD}} \pm 2.88$ & $85.71^{\mathrm{aA}} \pm 2.56$ & $70.43^{\mathrm{abc}} \pm 2.51$ & $73.14^{\mathrm{abc}} \pm 2.61$ & $77.00^{\mathrm{abB}} \pm 2.65$ \\
\hline & 14 & $67.43^{\mathrm{aE}_{ \pm}} \pm 2.07$ & $88.00^{\mathrm{aA}} \pm 1.91$ & $71.29^{\mathrm{aD}} \pm 3.55$ & $74.71^{\mathrm{ac}} \pm 2.29$ & $79.86^{\mathrm{aB}} \pm 3.08$ \\
\hline & 21 & $65.29^{a \mathrm{D}} \pm 2.98$ & $79.86^{\mathrm{bA}} \pm 2.41$ & $69.00^{a b c} \pm 3.21$ & $70.00^{\mathrm{bc}} \pm 2.08$ & $74.14^{\mathrm{bcB}} \pm 2.97$ \\
\hline
\end{tabular}

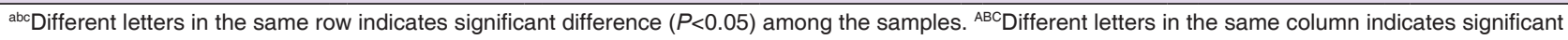
difference $(P<0.05)$ among the samples. LHM=Lactose hydrolyzed before fermentation at percentage 25,50 and $90 \%$ respectively. Co-hydrolyzed=Lactose hydrolysis and fermentation simultaneously. 
On the other hand, the mean flavour scores of all fermented camel milk samples increased during the first 14 days then declined significantly $(P<0.05)$ throughout the end of storage time. The results agreed with the findings of Salwa et al., (2003) and Ibrahim and Khalifa, (2015b) who found a decrease in flavour of yogurt at the end of storage period due to the development of acidity during storage.

Although, the average flavour scores of the co-hydrolysis and LHM 90\% treatments were very close scores, but the panelists preferred the flavour of the co-hydrolysis fermented milk. Furthermore, fermented camel milk made with LHM 90\% was rated as unacceptable because of its strong sweetness and the occurrence of an off-flavour. The most common by the panelist's criticisms were related to the semi-liquid texture of the control and LHM 25 and $50 \%$ treatments, also the non-typical fermented milk taste and flavour. These agreed with Nagaraj et al., (2009) and Martins et al., (2012) who found that the sensory quality of yogurt made from milk with $90 \%$ lactose hydrolysis had poor flavour.

On the other hand, the effect of the degree of lactose hydrolysis and co-hydrolysis on the fermented camel milk body and texture scores was found statistically significant $(P<0.05)$. The co-hydrolysis fermented camel milk had significantly $(P<0.05)$ higher ratings for body and texture scores which could be related to the increase in EPS concentration as mentioned above. Control, LHM 25 and $50 \%$ fermented camel milk showed the lowest acceptable scores, the tasters objecting to its liquid texture and nontypical fermented milk in body and texture. Our result agreed with other investigators as Attia et al., (2001) and Rahman et al., (2009) who reported that the fermentation camel milk was watery and precipitated in the form of flocks due to the presence of growth-inhibiting factors in the camel milk.

Although the highest viscosity and lower syneresis was achieved in LHM 90\% fermented camel milk, this product had less acceptable scores for body and texture by the panelists than co-hydrolysis fermented camel milk. The large differences in body and texture scores between all fermented camel milk samples would be probably due to the type and concentration of EPS-produced by starter cultures which acting as the thickener effect and caused increasing in texture, firmness, creaminess, and smoothness of fermented camel milk. However, the final textural characteristics of yogurt are strongly dependent on the type and degree of branching structure and properties of the EPS (Dupont et al., 2000; Folkenberg et al., 2005).

Moreover, the results showed that the color and appearance of the fermented camel milk differed significantly $(P<0.05)$ by the treatments. However, the panelists showed a preference for the color and appearance of the cohydrolysis fermented camel milk than control and other samples. Moreover, control, LHM 25 and 50\% fermented camel milk showed the lowest color and appearance acceptable scores, the panelists objecting to its liquid texture and broken of the gel structure which gives those treatments the lowest appearance acceptable scores.

During the 14 days of the storage period, the color and appearance of all fermented camel milk increased, and then declined significantly throughout the end of storage. This result was similar to that reported by Salwa et al., (2003) and Hanif et al., (2012) who noticed a decrease in the color and appearance scores of yoghurt during the end of the storage period due to wheying-off on the fermented milk surface which ultimately deteriorate the quality of fermented camel milk.

On the other hand, highly significant differences $(P<0.05)$ were recorded for the acidity panelists' scores between the co-hydrolysis fermented camel milk and other treatments, while no significant differences $(P<0.05)$ in relation to storage time. Moreover, the higher acidity scores were observed in the co-hydrolysis samples while the lowest were recorded in control, LHM 25 and 50\% treatments. This may refer to the salty taste of camel milk and the imbalance between salty and acidic taste in this treatment.

During the 14 days of the storage period there was an increase in the acidity scores for all fermented camel milk samples, then a decline at the end of the storage time. Similar results were noted by Hanif et al., (2012) who mentioned that the acidity development continued in yogurt during the storage even at $4^{\circ} \mathrm{C}$ and noticed marked differences in taste after one week of storage.

Additionally, the acidity scores of the LHM 90\% samples were, to some extent, less pronounced and somewhat intertwined with the salty taste of camel milk. The most common panelists criticisms were related to the higher sweeter taste in LHM 90\% samples than co-hydrolysis, which may be due to presence the higher level of glucose and galactose not used by the starter which seemed sufficient to impart the intensely sweet taste. This result agrees with Nagaraj et al., (2009), Wolf et al., (2015) and Schmidt et al., (2016) who confirmed that yogurts made from lactose hydrolysis gave a sweeter taste and lowers acid flavour.

In general, the fermented camel milk made with lactose hydrolysis and co-hydrolysis showed a highly significant $(P<0.05)$ effect on the scores assigned to the overall acceptability of all fermented camel milk samples 
than control. Furthermore, the mean values of overall acceptability scores of all fermented camel milk samples increased significantly $(P<0.05)$ during the first 14 days of the storage then declined at the end of 21 days of the storage period. These results agreed with the findings of Salwa et al., (2003) and Hanif, et al., (2012) who found a decrease in overall acceptability of yogurt samples during the end of cold storage.

However, the results of sensory evaluation of this study suggested that the co-hydrolysis fermented camel milk showed better sensory characteristics and was more liked by the panel of judges than those in control and other treated samples This may indicate a poor rheological characteristic and sensory characteristics for these treatments.

\section{CONCLUSION}

A positive effect of simultaneous lactic fermentation with enzymatic catalysis on the fermentation time, physiochemical and sensory characteristics of hydrolyzed fermented camel milk compared to the control samples was observed. The co-hydrolysis process improved the growth and viability of $S$. thermophilus and $L$. delbrueckii ssp. bulgaricus compared to the other treatments. Furthermore, during the first 6 hours of incubation, remarkable decrease in the $\mathrm{pH}$ and increase in the titratable acidity values in the co-hydrolysis fermented camel milk resulted in reduced fermentation time. The co-hydrolysis and LHM 90\% fermented milk was characterized by a higher amount of EPS produced and showed better rheological properties (more viscosity and decreases in syneresis) than other treatments, which caused an improvement in the weak body of fermented camel milk.Among sensory characteristics, the co-hydrolysis fermented camel milk got higher scores in all sensory characteristics (body and texture, flavor, acidity and color and appearance) while fermented camel milk made with LHM 90\% was rated as unacceptable because of its strong sweetness. However, the use of the co-hydrolysis as technique in making fermented camel milk would be allowed for the development of a well-fermented camel milk product with a significant quality in texture and all sensory characteristic scores and finallycreated new marketing product. Additional research would be needed to investigate the applications of $\beta$-galactosidase enzymes to other camel dairy products from a technological point of view.

\section{REFERENCES}

Akhmetsadykova, S. H., A. Baubekova, G. Konuspayeva, N. Akhmetsadykov, B. Faye and G. Loiseau. 2014. In: S. Lortal, B. Faye, C. Corniaux, M. Napoleone (Eds.), Industrial Production of
Starters for Traditional Fermented Milk Products. Actes des 1ères Rencontres Internationales "le lait, Vecteur de Développement, 21-23 Mai 2014, Rennes, France, Poster, p. 46.

Akhmetsadykova, S. H., A. Baubekova, G. Konuspayeva, N. Akhmetsadykov, N. Akhmetsadykov, Faye, B. and G. Loiseau. 2015. Lactic acid bacteria biodiversity in raw and fermented camel milk. Afr. J. Food Sci. Technol. 6(3): 84-88.

Al haj, O. A. and H. A. Al Kanhal. 2010. Compositional, technological and nutritional aspects of dromedary camel milk. Int. Dairy J. 20(12): 811-821.

Al-Juboori, A. T., M. Mohammed, J. Rashid, J. Kurian and S. ElRefaey. 2013. Nutritional and medicinal value of camel (Camelus dromedarius) milk. WIT Trans. Ecol. Environ. 170: 221-232.

Al-Zoreky, N. S. and M. M. Al-Otaibi. 2015. Suitability of camel milk for making yogurt. Food Sci. Biotechnol. 24(2): 601-606.

AOAC. 2005. Official Methods of Analysis. 16th ed. Association of Official Analytical Chemists, Washington, DC.

Attia, H., N. Kherouatou and A. Dhouib. 2001. Dromedary milk lactic acid fermentation: Microbiological and rheological characteristics. J. Ind. Microbiol. Biotechnol. 26(5): 263-270.

Cheng, H. 2010. Volatile flavor compounds in yogurt: A review. Crit. Rev. Food Sci. Nutr. 50: 938-950.

Dave, R. I. and N. P. Shah. 1997. Viability of yoghurt and probiotic bacteria in yoghurts made from commercial starter cultures. Int. Dairy J. 7: 31-41.

De Vin, F., P. Radstrom, L. Herman and L. de Vuyst. 2005. Molecular and biochemical analysis of the galactose phenotype of dairy Streptococcus thermophilus strains reveals four different fermentation profiles. Appl. Environ. Microbiol. 71(7): 3659-3667.

De Vuyst, L., M. Zamfir, F. Mozzi, T. Adriany, V. Marshall, B. Degeest and F. Vaningelgem. 2003. Exopolysaccharide producing Streptococcus thermophilus strains as functional starter cultures in the production of fermented milks. Int. Dairy J. 13(8): 707-717.

Degeest, B., F. Mozzi and L. De Vuyst. 2002. Effect of medium composition and temperature and $\mathrm{pH}$ changes on exopolysaccharide yields and stability during Streptococcus thermophilus LY03 fermentations. Int. J. Food Microbiol. 79(3): 161-174.

Dubois, M., K. A. Gilles, J. K. Hamilton, P. A. Rebers and F. Smith. 1956. Colorimetric method for determination of sugars and related substances. Anal. Chim. 38: 350-356.

Dupont, I., D. Roy and G. Lapointe. 2000. Comparison of exopolysaccharide production by strains of Lactobacillus rhamnosus and Lactobacillus paracasei grown in chemically defined medium and milk. J. Ind. Microbiol. Biotechnol. 24: 251- 255.

Farag, S. I., A. H. El-Sonbaty, S. A. Hussein, A. F. Farrag and A. M. Shahine. 2007. Effect of substituting added skim milk powder (SMP) with wheat Germ (WG) on the quality of goat's milk yoghurt and fermented camel's milk drink. Proc. 10th Egypt. Conf. Dairy Sci. Technol. 401: 315-336.

Faye, B. and P. Bonnet. 2012. Camel Sciences and Economy in the World: Current Situation and Perspectives. Proc. 3rd ISOCARD Conference. Keynote Presentations. 29th January to 1st February, 2012, Sultanate of Oman, pp. 2-15.

Faye, B. 2015. Role, distribution and perspective of camel breeding in the third millennium economies. Emir. J. Food. Agric. 27(4): 318-327.

Folkenberg, D. M., P. Dejmek, A. Skriver and R. Ipsen. 2005. Relation between sensory texture properties and exopolysaccharide distribution in set and in stirred yoghurts produced with different starter cultures. J. Texture Stud. 36: 174-189. 
Folkenberg, D. M., P. Dejmek, A. Skriver, H. S. Guldager and R. Ipsen. 2006. Sensory and rheological screening of exopolysaccharide producing strains of bacterial yogurt cultures. Int. Dairy J. 16: 111-118

Guler-Akin, M. B. and M. S. Akin. 2007. Effects of cysteine and different incubation temperatures on the microflora, chemical composition and sensory characteristics of bio-yogurt made from goat's milk. Food Chem. 100(2): 788-793.

Hanif, M. S., T. Zahoor, Z. Iqbal and A. A. Ihsan-ul-Haq. 2012. Effect of storage on rheological and sensory characteristics of cow and buffalo milk yogurt. Pak. J. Food Sci. 22(2): 61-70.

Harju, M., H. Kallioinen and O. Tossavainen. 2012. Lactose hydrolysis and other conversions in dairy products: Technological aspects. Int. Dairy J. 22(2): 104-109.

Hashim, I. B., A. H. Khalil and H. Habib. 2009. Quality and acceptability of a set-type yogurt made from camel milk. J. Dairy Sci. 92: 857-862.

Hassaïne, O., H. Zadi-Karam and N. E. Karam. 2007. Technologically important properties of lactic acid bacteria isolated from raw milk of three breeds of Algerian dromedary (Camelus dromedarius). Afr. J. Biotechnol. 6(14): 1720-1727.

Holzapfel, W. H. 2002. Appropriate starter culture technologies for small-scale fermentation in developing countries. Int. J. Food Microbiol. 75(3): 197-212.

Husain, Q. 2010. Beta-galactosidases and their potential applications: A review. Crit. Rev. Biotechnol. 30: 41-62.

Ibrahim, A. H. 2015a. Effect of milk supplementation with various types of milk proteins on physicochemical and microbiological properties of bio-fermented camel's milk. J. Food Dairy Sci. Mansoura Univ. 6(1): 1-22.

Ibrahim, A. H. 2015b. Effects of exopolysaccharide-producing starter cultures on physicochemical, rheological and sensory properties of fermented camel's milk. Emirates J. Food Agric. 27(4): 374-384.

Ibrahim, A. H. and S. A. Khalifa. 2015a. The effects of various stabilizers on physiochemical properties of camel milk yoghurt. J. Am. Sci. 11(1): 15-24.

Ibrahim, A. H. and S. A. Khalifa. 2015b. Improve sensory quality and textural properties of fermented camel's milk by fortified with dietary fiber. J. Am. Sci. 11(3): 42-54.

Isanga, J. and G. Zhang. 2009. Production and evaluation of some physicochemical parameters of peanut milk yoghurt. LWT Food Sci. Technol. 42: 1132-1138.

Ismail, A.A., G. Mogensen and P. R. Poulsen. 1983. Organoleptic and physical properties of yoghurt made from lactose hydrolysed milk. J. Soc. Dairy Technol. 32(2): 52-55.

Khalesi, M., M. Salami, M. Moslehishad, J. Winterburn and A. A. Moosavi-Movahedi. 2017. Biomolecular content of camel milk: A traditional super food towards future healthcare industry. Trends Food Sci. Technol. 62: 49-58.

Lin, W. J., D. A. Savaiano and S. K. Harlander. 1989. A method for determining $\beta$-galactosidase activity of yogurt cultures in skim milk1, 2. J. Dairy Sci. 72(2): 351-359.

Martins, A. R., R. L. Monteiro, J. F. D. M. Burkert and C. A. V. Burkert. 2012. Simultaneous enzymatic hydrolysis and lactic fermentation to obtain a yogurt with low lactose content. Ciência e Agrotecnol. 36(5): 551-559.

Martins, A. R., A. P. Manera, J. F. de Medeiros Burkert and C. A. V. Burkert. 2014. Improving galacto-oligosaccharide content in the production of lactose-reduced yogurt. Int. J. Eng. Res. Appl. 4(11): 84-89.

Mende, S., M. Peter, K. Bartels, T. Dong, H. Rohm and D. Jaros.
2013. Addition of purified exopolysaccharide isolates from $S$. thermophilus to milk and their impact on the rheology of acid gels. Food Hydrocoll. 32: 178-185.

Mortada, M. S. and I. A. H. Omer. 2013. Effect of fortifying camel's milk with skim milk powder on the physicochemical, microbiological and sensory characteristics of set yoghurt. Adv. J. Food Sci. Technol. 5(6): 765-770.

Mozzi, F., G. Rollan, G. Savoy de Giori and G. F. de Valdez. 2001. Effect of galactose and glucose on the exopolysaccharide production and the activities of biosynthetic enzymes in Lactobacillus casei CRL 87. J. Appl. Microbiol. 91: 160-167.

Nagaraj, M., B. Sharanagouda, H. Manjunath and M. Manafi. 2009. Standarization of different levels of lactose hydrolysis in the preparation of lactose hydrolyzed yoghurt. Iran. J. Vet. Res. 10: 132-136.

Rahman, I. E. A., H. A. Dirar and M. A. Osman. 2009. Microbiological and biochemical changes and sensory evaluation of camel milk fermented by selected bacterial starter cultures. Afr. J. Food Sci. 3(12): 398-405.

Ramchandran, L. and N. P. Shah. 2009. Effect of EPS on the proteolytic and ACE-inhibitory activities and textural and rheological properties of low-fat yogurt during refrigerated storage. J. Dairy Sci. 92: 895-906.

Ranadheera, C. S., C. A. Evans, M. C. Adams and B. K. Baines. 2012. Probiotic viability and physico-chemical and sensory properties of plain and stirred fruit yogurts made from goat's milk. Food Chem. 135(3): 1411-1418.

Ruas-Madiedo, P. and P. Zoon. 2003. Effect of exopolysaccharideproducing Lactococcus lactis strains and temperature on the permeability of skim milk gels. Colloids Surf. A Physicochem. Eng. Asp. 213: 245-253.

Sagar, S. P., B. M. Mehta, K. N. Wadhwani, V. B. Darji and K. D. Aparnathi. 2016. Evaluation of camel milk for selected processing related parameters and comparisons with cow and buffalo milk. Int. J. Health Anim. Sci. Food Saf. 3: 27-37.

Sahan, N., K. Yasar and A. A. Hayaloglu. 2008. Physical, chemical and flavor quality of non-fat yogurt as affected by a $\beta$-glucan hydrocolloidal composite during storage. Food Hydrocoll. 22: 1291-1297.

Sakandar, H. A., M. Imran, N. Huma, S. Ahmad. and H. K. W. Aslam. 2014. Effects of polymerized whey proteins isolates on the quality of stirred yoghurt made from camel milk. J. Food Process Technol. 5: 350-355.

Salwa, A. A., E. A. Galal and N. A. Elewa. 2003. Carrot yoghurt: Sensory, chemical, microbiological properties and consumer acceptance. Pak. J. Nutr. 3: 322-330.

Schmidt, C., S. Mende, D. Jaros and H. Rohm. 2016. Fermented milk products: Effects of lactose hydrolysis and fermentation conditions on the rheological properties. Dairy Sci. Technol. 96(2): 199-211.

Shihata, A. and N. P. Shah. 2002. Influence of addition of proteolytic strains of Lactobacillus delbrueckii subsp. bulgaricus to commercial ABT starter cultures or texture of yoghurt, exopolysaccharide production and survival of bacteria. Int. Dairy J. 12: 765-772.

Shori, A. B. and A. S. Baba. 2012. Viability of lactic acid bacteria and sensory evaluation in Cinnamomum verum and Allium sativum bio-yogurts made from camel and cow milk. J. Assoc. Arab Univ. Basic Appl. Sci. 11(1): 50-55.

Shori, A. B., A. S. Baba, M. Misran and H. W. Tan. 2013. Enrichment of yogurt made from camel milk with Allium sativum and Cinnamomum verum: Influence on syneresis, water holding capacity, exopolysaccharides and rheological properties. Camel, 1(1): 51-63. 
SPSS Package (SPSS v.20). 2012. Software Package for Social Science for Windows. SPSS Amos.

Thomas, T. D. and V. L. Crow. 1983. Lactose and sucrose utilization by Streptococcus thermophilus. FEMS Microbiol. Lett. 17: 13-17.

Toba, T., K. Arihara and S. Adachi. 1986. Quantitative changes in oligosaccharides during fermentation and storage of yogurt inoculated simultaneously with starter culture and $\beta$-galactosidase preparation. J. Dairy Sci. 69: 1241-1245.

Torriani, S., F. Gardini, M. Guerzoni and F. Dellaglio. 1996. Use of response surface methodology to evaluate some variables affecting the growth and acidification characteristics of yogurt cultures. Int. Dairy J. 6: 625-636.

Vénica, C. I., C. V. Bergamini, C. A., Zalazar and M. C. Perotti. 2013. Effect of lactose hydrolysis during manufacture and storage of drinkable yogurt.' J. Food Nutr. Disord. 2(5): 1-7.

Vénica, C. I., M. C. Perotti and C. V. Bergamini. 2014. Organic acids profiles in lactose-hydrolyzed yogurt with different matrix composition. Dairy Sci. Technol. 94(6): 561-580.

Vinderola, C. G., N. Bailo and J. A. Reinheimer. 2000. Survival of probiotic microflora in Argentinian yoghurts during refrigerated storage. Food Res. Int. 33(2): 97-102.

Wolf, I. V., C. I. Vénica and M. C. Perotti. 2015. Effect of reduction of lactose in yogurts by addition of $\beta$-galactosidase enzyme on volatile compound profile and quality parameters. Int. J. Food Sci. Technol. 50(5): 1076-1082.

Zisu, B. and N. P. Shah. 2003. Effects of pH, temperature, supplementation with whey protein concentrate, and adjunct cultures on the production of exopolysaccharide by Streptococcus thermophilus 1275. J. Dairy Sci. 86: 3405-3415. 